\title{
Respiration rates in shallow lakes of different types: contribution of benthic microorganisms, macrophytes, plankton and macrozoobenthos
}

\author{
Janusz Żbikowski · Tatjana Simčič • Franja Pajk • Małgorzata Poznańska-Kakareko • \\ Tomasz Kakareko $\cdot$ Jarosław Kobak
}

Received: 13 February 2018/Revised: 9 October 2018/ Accepted: 20 October 2018/Published online: 30 October 2018

(C) The Author(s) 2018

\begin{abstract}
The determination of the metabolic activity of organisms at various trophic levels is crucial for the proper assessment of the energy flow through the ecosystem, which is the basic process determining ecosystem functioning. We estimated the respiration rate in nine shallow, eutrophic lakes (macrophytedominated and phytoplankton-dominated) from northeastern Poland. Respiratory carbon loss (RCL) through bottom microbial communities, macrophytes, plankton and macrozoobenthos was estimated by measuring the Electron Transport System activity. The shares of the particular ecosystem components in
\end{abstract}

Handling editor: Stefano Amalfitano

Electronic supplementary material The online version of this article (https://doi.org/10.1007/s10750-018-3807-5) contains supplementary material, which is available to authorized users.

J. Żbikowski ( $)$ ) T. Kakareko

Department of Hydrobiology, Faculty of Biology and

Environmental Protection, Nicolaus Copernicus

University, Toruń, Poland

e-mail: jzbikow@umk.pl

T. Simčič · F. Pajk

Department of Organisms and Ecosystems Research,

National Institute of Biology, Ljubljana, Slovenia

M. Poznańska-Kakareko · J. Kobak

Department of Invertebrate Zoology, Faculty of Biology

and Environmental Protection, Nicolaus Copernicus

University, Toruń, Poland respiration processes differed among the lake types and seasons. The bottom microbial communities contributed most to the RCL (from 50\% in the macrophyte-dominated lakes to $90 \%$ in the shallower phytoplankton-dominated lakes) except in macrophytes-dominated lakes in summer, where the macrophyte contribution prevailed $(80 \%)$. The contribution of plankton was considerable only in the deeper phytoplankton-dominated lakes (20\%). Macrozoobenthos was important $(20 \%)$ only in the macrophytedominated lakes in spring and autumn. The RCL through bottom microbial communities was substantially higher in the shallow lakes (especially phytoplankton-dominated) than in deep, stratified eutrophic lakes. Shallow eutrophic lakes can be highly productive due to intensive organic matter mineralization at the bottom and rapid flow and cycling of carbon and nutrients resulting from their polymictic character.

Keywords Shallow lakes - ETS activity · Respiratory carbon loss $\cdot$ Abiotic parameters

\section{Introduction}

Energy flow is one of the basic processes determining ecosystem functioning. As most of the energy leaving the ecosystem is associated with respiration (Simčič, 2005; Kominoski et al., 2018), the determination of the metabolic activity of organisms at various trophic 
levels is crucial for the proper assessment of the energy flow through the ecosystem. It should be emphasized that the role of a given organism in the ecosystem depends not only on its abundance, but also on its metabolic activity, which can be estimated by its respiration rate, expressed per unit biomass (Devol, 1979; Simčič, 2005; McKinnon et al., 2015). Respiration recycles organic carbon arising from photosynthesis back to inorganic carbon and therefore affects net balances of carbon in aquatic ecosystems (Pace \& Prairie, 2005). Therefore, knowledge of the intensity of metabolic processes occurring in the water column and bottom sediments is necessary for comprehensive understanding of the structure and functioning of aquatic ecosystems (Pace \& Prairie, 2005; Simčič \& Brancelj, 2009; Lischke et al., 2017).

It should be noted that the impact of environmental factors on the respiration rate of key biocoenotic components in lakes is still poorly known, apart from temperature (Staehr \& Sand-Jensen, 2006; Simčič \& Germ, 2010). So far, the role of various biocoenotic components in the metabolic process has been investigated in deep, stratified lakes, usually of low trophic level (G.-Tóth et al., 1995; Jonsson et al., 2001; Åberg et al., 2004; Simčič, 2005; Simčič \& Brancelj, 2009; Simčič \& Germ, 2009; Germ \& Simčič, 2011; Tammeorg et al., 2017). On the other hand, considerably fewer studies have been devoted to shallow, polymictic and eutrophic lakes (G.-Tóth, 1992; Brothers et al., 2013; Zimmer et al., 2016; Lischke et al., 2017). Moreover, there is still insufficient knowledge in particular on seasonal changes in metabolic activity in various biocoenotic components in shallow lakes of different types (Vachon et al., 2017). It has been demonstrated that inland waters constitute a significant component of the global carbon cycle (Tranvik et al., 2009). Therefore our knowledge of this topic should be improved to gain better insight into the functioning of such lakes.

Shallow lakes differ from deep, stratified ones in many aspects which may affect metabolic activity. The most important differences include the lack of stable thermal stratification in shallow lakes, so that the whole water column is mixed easily and frequently, increasing the impact of sediment-water interface processes on the functioning of the entire water body (Jensen \& Andersen, 1992; Søndergaard et al., 2003; de Vicente et al., 2006; Filbrun et al., 2013; Martinsen et al., 2017). Scheffer (1990) has distinguished two types of shallow lakes: (1) macrophyte-dominated lakes, with the entire bottom overgrown by submerged plants due to their high water transparency, and (2) phytoplankton-dominated lakes, with turbid water and macrophytes limited to their littoral zones. Furthermore, Żbikowski \& Kobak (2007) have demonstrated that the intensity of light reaching the bottom is an important factor shaping the structure of pelophilous macrozoobenthos and physico-chemical parameters of the bottom sediments. Therefore, they further divided phytoplankton-dominated lakes into shallower and deeper lakes, depending on whether the euphotic zone reaches the bottom or not, respectively.

Given this distinctness of shallow lakes, the determination of the role of particular groups of organisms in the metabolism of organic matter in these water bodies would be a valuable augmentation of the earlier results, as the functioning of shallow lakes cannot be predicted on the basis of our knowledge of deep, stratified lakes. Respiration rate and the contributions of particular biocoenotic components in this process are likely to differ between shallow and deep, stratified lakes, as depth-dependent factors, such as thermal stratification, considerably affect near-bottom water oxygen concentrations and consequently rates of aerobic and anaerobic respiration of the microbial communities in bottom sediments (den Heyer \& Kalff, 1998; Petersen \& Chen, 1999; Daniels et al., 2015). Depth also affects the role of plankton due to different availability of nutrients (Devol, 1979; Simčič, 2005; Simčič \& Germ, 2009), as well as that of macrozoobenthos (Jónasson et al., 1990; Lindegaard, 1994; Kurashov, 2002; Lischke et al., 2017) in metabolism of organic matter. Moreover, the share of the main groups of primary producers (i.e. macrophytes, phytoplankton and microphytobenthos) in lake metabolism is also likely to differ between shallow and deep, stratified lakes.

Respiratory carbon loss (RCL) through microorganisms in the bottom sediments and other biocoenotic components (plankton, zoobenthos, macrophytes) was estimated by measuring the Electron Transport System (ETS) activity, which is closely correlated to oxygen consumption $(R)$ (Kenner \& Ahmed, 1975a; Owens \& King, 1975; del Giorgio, 1992; Packard et al., 2015). ETS activity indicates the amount of oxygen consumption that would occur if all 
enzymes functioned at their maximum activity (Muskó et al., 1995). The ETS assay has proved to be a good tool for estimating the potential metabolic activity of zooplankton (Owens \& King, 1975; James, 1987; Simčič \& Brancelj, 1997; Hernández-León et al., 2001; Simčič \& Brancelj, 2009; Osma et al., 2016), microplankton (Kenner \& Ahmed, 1975b; Devol \& Packard, 1978; Packard, 1985; Simčič \& Germ, 2009; Packard et al., 2015), macrozoobenthos (Muskó et al., 1995; Simčič, 2005; Simčič \& Germ, 2009; Moreira et al., 2017), macrophytes (Peñuelas et al., 1988; Szabó, 2003; Simčič \& Germ, 2009; Germ \& Simčič, 2011) and microorganisms in sediments (G.-Tóth et al., 1994; Simčič \& Brancelj, 2002; de Vicente et al., 2006; Simčič \& Brancelj, 2009; Germ \& Simčič, 2011; Krausz et al., 2012).

The main goal of the present study was to estimate the rate of respiratory metabolism in shallow, eutrophic lakes of various types by microorganisms in the bottom sediments and the rates of oxidation of organic matter by selected groups of organisms (macrophytes, plankton and bottom fauna), as well as to determine their importance in the process of respiration, taking seasonal changes into account. An additional goal of the study was to find relationships between the metabolic rate and selected abiotic parameters as well as some structural characteristics (density, biomass) of the selected groups of organisms. These data may help identify those parts of the ecosystems of shallow lakes which contribute most to the oxidation of organic matter through respiration, thus being crucial for their functioning, protection and conservation.

We hypothesized that (1) the RCL in the studied lakes would mainly take place on the bottom due to their shallow depth resulting in a high temperature of the sediments during the vegetation period and the lack of long-term oxygen depletions. Therefore, we expected a high impact of microorganisms from the bottom sediments on the total RCL in the lakes. We also assumed that (2) RCL should be highest in summer due to higher water and bottom temperature. Moreover, we expected that (3) macrophytes would considerably contribute to the RCL in macrophytedominated lakes, whereas (4) the share of RCL through plankton in phytoplankton-dominated lakes would be positively related to their depth.

\section{Materials and methods}

Study area

The study was conducted in nine shallow lakes situated in north-eastern Poland (Fig. 1.). The basic characteristics of the lakes are shown in Table 1. Most of them are small water bodies, with an area of a few dozen ha, except Lakes Karaś and Iławskie. At the beginning of the study, three of the lakes were dominated by macrophytes and the other six lakes were dominated by phytoplankton. The latter can be divided into shallower (three lakes, $0.9-1.5 \mathrm{~m}$ of maximum depth), and deeper (three lakes, 2.5-5.7 m). However, during the study period (in summer) the status of two lakes unexpectedly changed. In Lake Zielone, which was initially dominated by vascular flora, submerged macrophytes disappeared and the lake changed its status from macrophyte to phytoplankton domination. In contrast, in Lake Gardzień, which at the beginning of the study was dominated by phytoplankton, submerged plants appeared in summer and the lake switched its status from phytoplankton to macrophyte domination. This gave us a unique opportunity to observe the changes in the proportions of the microorganisms in the bottom sediments, as well as of macrophytes, plankton and macrozoobenthos in RCL during the alteration of its alternative state. Sampling stations (one station in each lake) were located in the most representative central part of each lake determined in the previous long-term studies based on several sampling sites in each lake (Żbikowski, 2011), at a depth slightly shallower than the maximum depth. The investigated lakes had no permanent vertical stratification, as shown by the lack of considerable differences in abiotic parameters between the surface and near-bottom water (data not shown). As the lakes being studied differ from one another in depth, bottom coverage by plants and their taxonomic composition, wind exposure and catchment type (Table 1), the results can be considered generally representative for a wide range of conditions occurring in lowland, eutrophic shallow lakes.

Sampling strategy and sample treatments

The study was carried out in spring (19-21 May), summer (23-25 August) and autumn (21-23 
Fig. 1 Location of the studied lakes in Poland

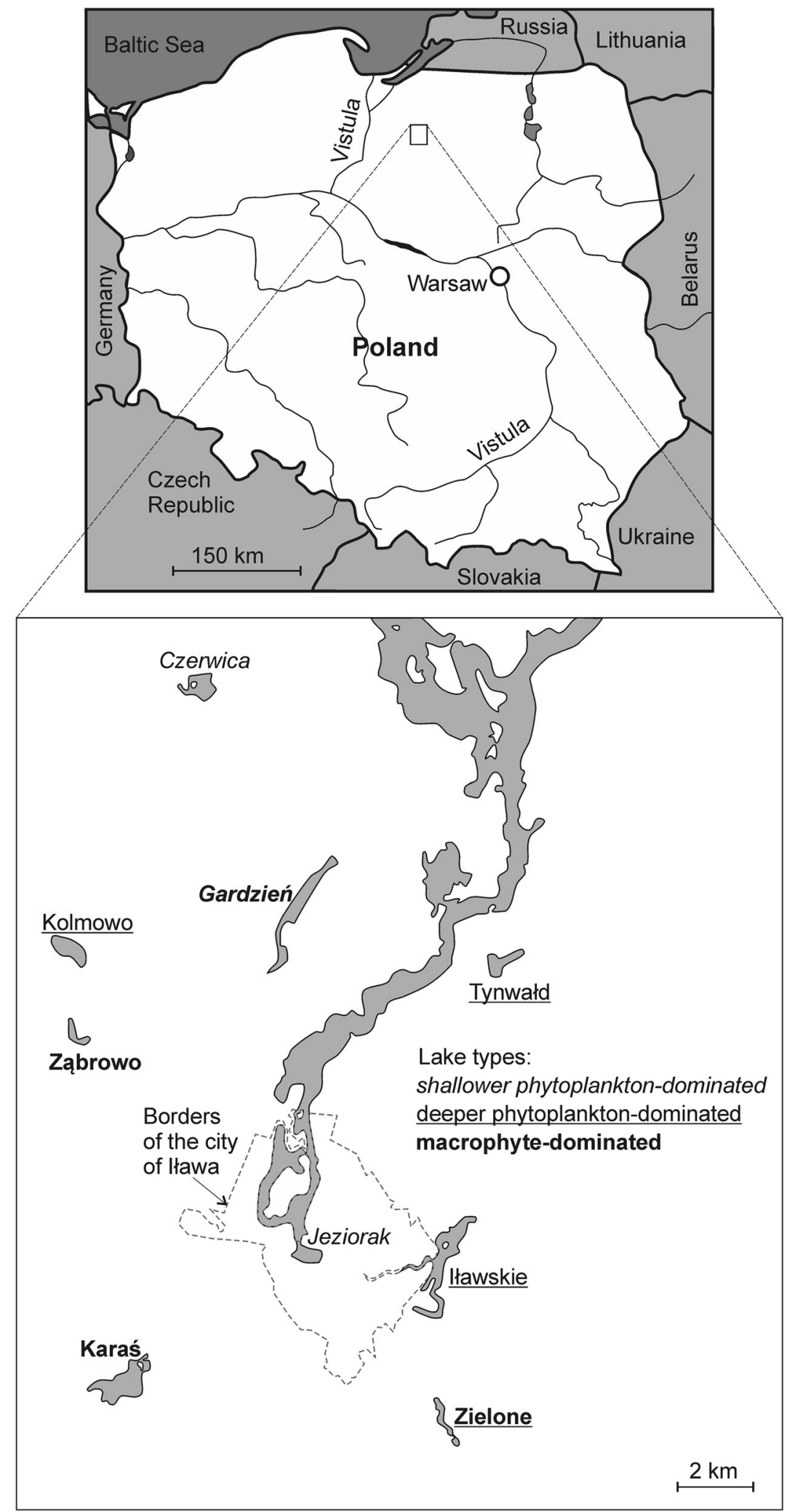




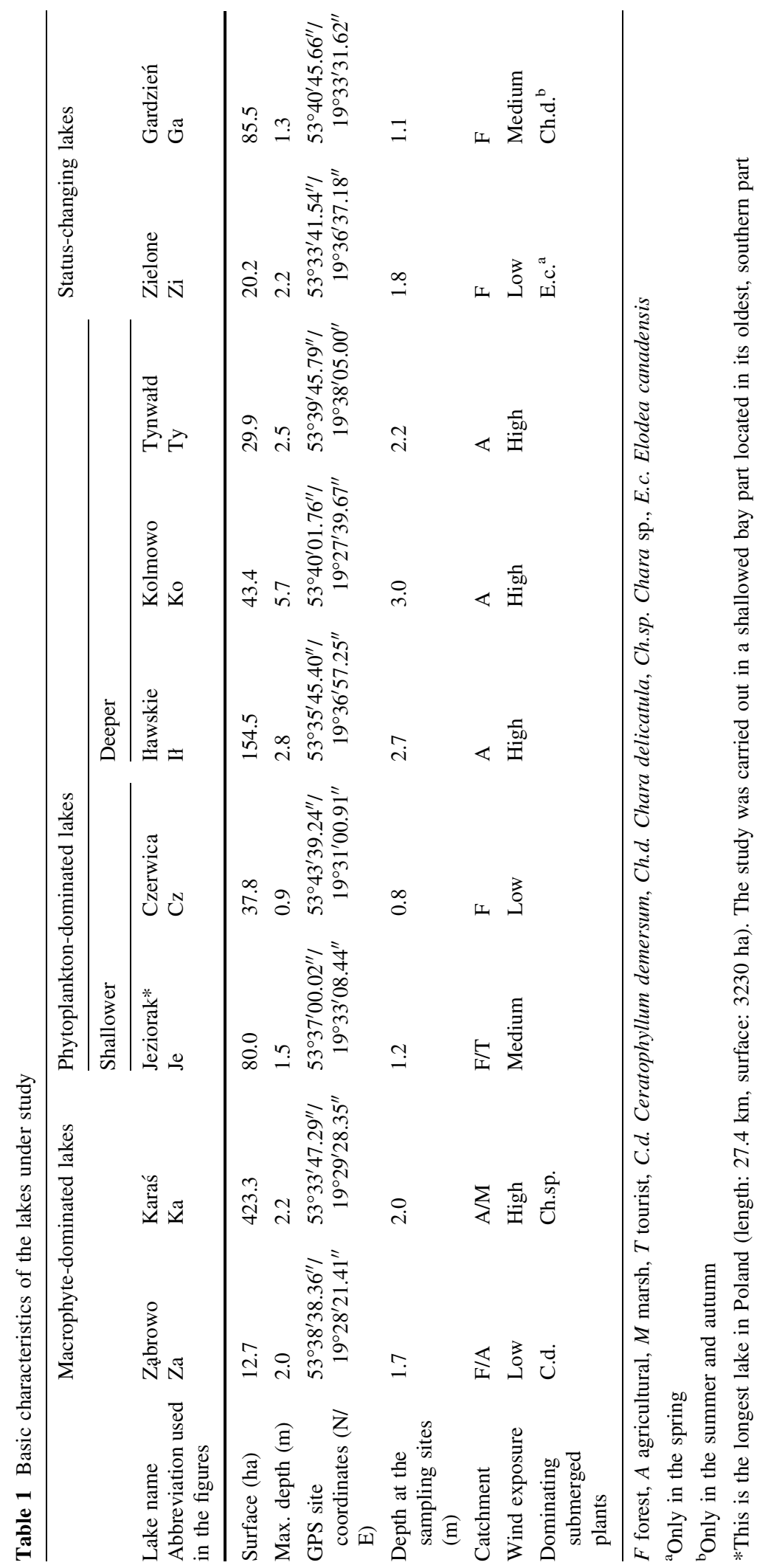


November) of 2010. In spring and summer the samples were taken from each lake whereas in autumn it was not possible to take samples from Lakes Zielone and Tynwałd for technical reasons.

To determine the ETS activity of plankton, two 1.5$\mathrm{dm}^{3}$ water samples were collected from each lake from the depth of ca. $0.5 \mathrm{~m}$ below the surface. In the laboratory, the samples were prefiltered through $120 \mu \mathrm{m}$ mesh and rinsed with distilled water to minimize bacteria and algae adhering to the body surface of larger plankton that remained on the mesh (2 replicates). For ETS activity analysis, live plankton samples (predominantly zooplankton) were collected and stored in Eppendorf tubes using forceps and a dripping-tube. The water with smaller particles that passed through the mesh was filtered through a glass microfibril filter (Whatman $\mathrm{GF} / \mathrm{C}$; particle retention approximately $1 \mu \mathrm{m})$. Material remaining on the filter (mainly phytoplankton) was stored in Eppendorf tubes together with the filter (2 replicate samples). ETS activity was measured separately in larger$(>120 \mu \mathrm{m})$ and smaller-sized $(<120 \mu \mathrm{m})$ plankton fractions due to further calculations of respiration rates.

Submerged vegetation biomass was sampled using a frame with a net bag $\left(0.16 \mathrm{~m}^{2}, 3\right.$ replicate samples). The stems and leaves of the middle part of a fresh shoot were taken for ETS activity analysis and stored in Eppendorf tubes (2 replicate samples).

To collect the bottom fauna, in the macrophytedominated lakes we used a core sampler (catching area $40 \mathrm{~cm}^{2}, 7-10$ replicate samples depending on the macrozoobenthos abundance, ca. $30 \mathrm{~cm}$ layer of sediments) whereas in the lakes with phytoplankton domination we used an Ekman-Birge grab (catching area $225 \mathrm{~cm}^{2}, 2-4$ replicate samples). As muddy sediments of shallow lakes have high water content, the grab could penetrate them deeper than the surface layer inhabited by macrozoobenthos. Therefore the grab was covered with $0.5-\mathrm{mm}$ mesh, which prevented collected organisms from escaping through the top of the device. The samples were rinsed using a $0.5 \mathrm{~mm}$ sieve and preserved in $4 \%$ formaldehyde for biomass assessment. For ETS activity analysis, non-preserved macroinvertebrates were stored after sieving and taxonomic determination in Eppendorf tubes.

For ETS activity determination, fresh bottom sediments ( $0-5 \mathrm{~cm}$ top layer), collected with the same core sampler as that used for collecting macrozoobenthos in macrophyte-dominated lakes, were homogenized with a glass stick and stored in Eppendorf tubes (2 replicate samples).

All samples for ETS activity measurements were stored at $-80{ }^{\circ} \mathrm{C}$ in Eppendorf tubes until being transported in dry ice to the laboratory of the National Institute of Biology in Ljubljana, where they were analysed for ETS activity.

\section{ETS activity}

ETS activity was measured using the assay originally proposed by Packard (1971), and modified by many authors (Kenner \& Ahmed, 1975b; Owens \& King, 1975; G.-Tóth, 1999). Before measurements macrozoobenthos (0.1-65 mg wet mass), submerged macrophytes (16-85 mg) and sediment samples (27-58 mg) were weighed on an electrobalance (Sartorius BP 210 $\mathrm{S}$, Goettingen, Germany) with $0.1 \mathrm{mg}$ accuracy. Samples of plankton, macrozoobenthos and macrophytes were homogenized in $4 \mathrm{~cm}^{3}$ of ice-cold homogenization buffer $(0.1 \mathrm{M}$ sodium phosphate buffer $\mathrm{pH}=8.4,75 \mu \mathrm{M} \mathrm{MgSO}_{4}, 0.15 \%(\mathrm{w} / \mathrm{v})$ polyvinyl pyrrolidone, $0.2 \%(\mathrm{v} / \mathrm{v})$ Triton-X-100) using a Potter-Elvehjem tissue homogenizer (Eurostar; Ika Labortechnik, Staufen, Germany) for $3 \mathrm{~min}$ at $600 \mathrm{rpm}$ followed by an ultrasonic homogenizer (4710; Cole-Parmer, Vernon Hills, IL, USA) for $20 \mathrm{~s}$ at $40 \mathrm{~W}$. The sediment samples were homogenized in $4 \mathrm{~cm}^{3}$ of ice-cold homogenization buffer using an ultrasonic homogenizer for $3 \mathrm{~min}$ at $40 \mathrm{~W}$. The homogenates were centrifuged for $4 \mathrm{~min}$ at $0{ }^{\circ} \mathrm{C}$ at $10000 \mathrm{rpm}$ (2K15, Sigma, St. Louis, USA). Within $10 \mathrm{~min}, 0.5 \mathrm{~cm}^{3}$ of supernatant (in triplicate) was incubated in $1.5 \mathrm{~cm}^{3}$ substrate solution $(0.1 \mathrm{M}$ sodium phosphate buffer $\mathrm{pH} 8.4,1.7 \mathrm{mM}$ NADH, $0.25 \mathrm{mM}$ NADPH, $0.2 \%$ (v/v) Triton-X-100) with $0.5 \mathrm{~cm}^{3}$ INT (2.5 mM 2-p-iodo-phenyl 3-p-nitrophenyl 5-phenyl tetrazolium chloride) for $40 \mathrm{~min}$ at standard $\left(20^{\circ} \mathrm{C}\right)$ temperature. The reaction was stopped by adding $0.5 \mathrm{~cm}^{3}$ of stopping solution [formalin: $\mathrm{H}_{3} \mathrm{PO}_{4}$ conc. $=1: 1(\mathrm{v} / \mathrm{v})]$. Blanks $\left(1.5 \mathrm{~cm}^{3}\right.$ substrate solution and $0.5 \mathrm{~cm}^{3}$ INT solution) were incubated and treated as for the samples, followed by addition of $0.5 \mathrm{~cm}^{3}$ of homogenate (G.-Tóth, 1999). The formazan production was determined spectrophotometrically (WTW photoLab-Spectral, Weilheim, Germany) by measuring $\mathrm{A}^{490 \mathrm{~nm}}$ against the blank. ETS activity was measured as the rate of tetrazolium dye reduction, 
and converted to equivalent oxygen utilized in a given time interval as described by Kenner \& Ahmed (1975b). ETS activities of larger- and smaller-sized plankton fractions were first calculated per water volume $\left(\mathrm{mm}^{3} \mathrm{O}_{2} \mathrm{dm}^{-3} \mathrm{~h}^{-1}\right)$, and then multiplied by the volume of the water column above the bottom area of $1 \mathrm{~m}^{2}$ at the sampling stations to obtain the plankton ETS activities per unit surface area $\left(\mathrm{cm}^{3} \mathrm{O}_{2} \mathrm{~m}^{-2} \mathrm{~h}^{-1}\right)$. Sediment, macrophyte and macrozoobenthos ETS activities, calculated per wet mass $\left(\mathrm{mm}^{3} \mathrm{O}_{2} \mathrm{~g}^{-1}\right.$ $\mathrm{h}^{-1}$ ), were multiplied by the wet mass of $10 \mathrm{dm}^{3}$ of the sediments (the area of $1 \mathrm{~m}^{2}$ and a depth of $1 \mathrm{~cm}$ ), by the fresh biomass of macrophytes covering the area of $1 \mathrm{~m}^{2}$ or by the number of individuals of particular macrozoobentos species per $\mathrm{m}^{2}$, respectively.

The Arrhenius equation was used to convert the ETS activity at the incubation temperature $\left(\mathrm{ETS}_{\text {inc. }}\right.$, $\left.T_{\text {inc. }}\right)$ to that at the in situ temperature $\left(\mathrm{ETS}_{\text {in situ, }}\right.$ $\left.T_{\text {in situ }}\right)$ :

$\operatorname{ETS}_{\text {in situ }}=\operatorname{ETS}_{\text {inc. }} \mathrm{e}^{E_{\mathrm{a}}\left(1 / T_{\text {inc. }}-1 / T_{\text {in situ }}\right) / R}$,

where $E_{\mathrm{a}}$ is the activation energy (a value of $15 \mathrm{kcal} \mathrm{mol}^{-1}$ was used as this value was reported in previous studies; Owens \& King, 1975; Packard et al., 1975; Bamstedt, 1980), T the absolute temperature and $\mathrm{R}$ the gas constant.

As ETS activity measurements show the potential metabolic rate of organisms, they need to be converted to in vivo respiration rates by using empirically determined factors for the respective group of organisms (i.e. ETS/R ratio) in order to assess RCL through selected components (G.-Tóth, 1992; G.-Tóth et al., 1995; Simčič, 2005; Simčič \& Germ, 2009; Packard et al., 2015). Respiratory carbon loss (RCL) of the organisms was estimated using ETS/ $R$ ratios of 2.0 for larger-sized plankton fraction (zooplankton dominated) (Bamstedt, 1980; James, 1987; Simčič \& Brancelj, 1997), 7.0 for smaller-sized plankton fraction (phytoplankton-dominated) (Kenner \& Ahmed, 1975a; Packard, 1985), 2.8 for macrozoobenthos (Simčič, 2005), 4.0 for macrophytes (Peñuelas et al., 1988) and 5.0 for sediments (Simčič \& Brancelj, 2002). Respiratory carbon loss was calculated using the conversion factor $1 \mathrm{~cm}^{3} \quad \mathrm{O}_{2}=0.54 \mathrm{mg} C_{\mathrm{org}}$ (Lampert, 1984). In converting respiration to carbon units, a respiratory quotient (RQ) of 1.0 was assumed. Depths at the sampling stations were used in calculations of plankton metabolic activities per $\mathrm{m}^{2}$.
Respiratory carbon losses for smaller- and largersized plankton fractions were first calculated separately and then data for both fractions were pooled.

\section{Abiotic parameters}

Together with the collection of submerged macrophytes, plankton and macrozoobenthos samples, several abiotic parameters of water and sediments were determined. Water transparency was measured with a Secchi disc. To calculate the vertical attenuation coefficient of light under water (Scheffer, 1998: 22, Eq. 2) a Slandi LX204 (Slandi Sp. z o.o., Michałowice, Poland) luxometer was used. Temperature, conductivity and oxygen concentration at the surface and in the near-bottom water layer $(2-3 \mathrm{~cm}$ above the sediments) were measured by taking water and sediment samples with the core sampler and analysing it with a MultiLine P4 (WTW GMBH, Weilheim Germany) Universal Pocket Sized Meter. Total phosphorus concentration was analysed spectrophotometrically as molybdate reactive phosphorus after digestion with sulphuric acid and peroxide (Lewandowski et al., 2003).

Prior to the analyses of bottom sediments, macroinvertebrates and visible plant remains were removed from the sediment samples. Water content in the sediments (WC) was measured by oven-drying sediments to a constant mass at $104{ }^{\circ} \mathrm{C}$ for $24 \mathrm{~h}$. Organic matter content (OC) in sediments was determined after igniting dried sediments at $550{ }^{\circ} \mathrm{C}$ for $2 \mathrm{~h}$. The latter parameter was expressed in two ways, as: (1) the percentage of dry mass of sediments (Hakanson \& Jansson, 1983: 76, Eq. 2) and (2) milligrammes of dry mass per unit fresh sediment volume $\left(10 \mathrm{~cm}^{3}\right)$ according to the formula:

$\mathrm{OCmg}=\frac{\mathrm{DM} \times \mathrm{OC} \%}{100}$

where OCmg is the dry mass of organic matter in $10 \mathrm{~cm}^{3}$ of fresh sediments in milligrammes, DM the dry mass of $10 \mathrm{~cm}^{3}$ of fresh sediments in milligrammes, OC\% the percentage of dry mass of organic matter in sediments.

The difference between these two quantities consists in the variable water content in sediments. Namely, if the percentages of organic matter in the dry mass of the sediments are equal, the sediments with the lower water content will have more 
milligrammes of organic matter per unit of their fresh volume. The former value is a standard method of presenting $\mathrm{OC}$ in bottom sediments.

Sediment oxygen demand (SOD) was estimated by adding $300 \mathrm{~cm}^{3}$ of $100 \%$-oxygen saturated tap water to a special dish containing $20 \mathrm{~cm}^{3}$ of fresh sediments (2 replicates). The diameter of an oxygen sensor matched tightly the outlet of the dish, which prevented the oxygen exchange with the outside. The dish walls were impenetrable to light in order to prevent the production of oxygen as a result of benthic algae photosynthesis. The oxygen uptake was measured after $1 \mathrm{~h}$ at $20{ }^{\circ} \mathrm{C}$ (controlled room temperature) using the MultiLine P4 multimeter and oxygen sensor WTW CellOx 325. The preliminary trials showed that the oxygen concentration did not change ca. 15 min after the end of the oxygenation process, so we assumed that oxygen losses in pure tap water would be negligible. The sediments were kept in resuspension by means of a magnetic stirrer to sustain the water flow around the membrane of the oxygen sensor.

An important aim of the study was to search for correlations between the measured ecosystem parameters presented in Table 2 and the metabolic potential of organisms at various trophic levels, expressed as RCL at in situ temperature. The only exception was SOD, which was measured at $20{ }^{\circ} \mathrm{C}$ in the laboratory, thus we correlated it with RCL at the same temperature.

\section{Statistical analysis}

We used a General Linear Model with Lake type as a between-subject factor and Season as a within-subject factor to check the differences in abiotic parameters and zoobenthos biomass. The status-changing lakes were excluded from this analysis. We applied a General Linear Model with Lake type as a betweensubject factor and Season and Ecosystem component (microorganisms from the sediments, macrophytes, plankton, macrozoobenthos) as within-subject factors to test the determinants of RCL (log-transformed to reduce the departures from normality and homoscedasticity assumptions) in the studied lake types. The status-changing lakes were excluded from this analysis.

Moreover, linear Pearson correlations of RCL through vascular plants and macrozoobenthos with their biomasses were calculated. The variables selected for the correlation analysis of the plankton and sediment RCLs are indicated in Table 2. In the Results section only statistically significant correlations are reported.

Statistical calculations were carried out with SPSS Statistics v.23 (IBM Corporation, Armonk, USA).

\section{Results}

Environmental parameters

Temperatures in the studied lakes were $15.6 \pm 2.0{ }^{\circ} \mathrm{C}$ (mean $\pm \mathrm{SD}$ ) in spring, $22.5 \pm 1.3{ }^{\circ} \mathrm{C}$ in summer and $5.3 \pm 0.5^{\circ} \mathrm{C}$ in autumn. Obviously, temperature varied significantly with season, but not with the lake type (Supplementary Table 1), though the spring temperatures tended to be higher in the shallower lakes than elsewhere (Table 2). Other physical and chemical parameters of water and bottom sediments (Table 2) did not exhibit substantial inter-seasonal variability, except for a marginally significant effect of season on the water transparency (measured as Secchi depth, SD) (Supplementary Table 1). In most cases, these parameters did not differ clearly among the distinguished lake types, except water transparency and euphotic depth/lake depth ratio (Supplementary Table 1).

On the basis of the total phosphorus concentration (Table 2), most of the studied lakes can be classified as eutrophic or hypertrophic (Nürnberg, 1996). Water transparency was clearly higher in the macrophytedominated lakes (SD 1.6-2.4 m) than in the phytoplankton-dominated lakes $(0.4-0.7 \mathrm{~m})$. Moreover, Secchi depth values slightly increased with time, reaching $0.84 \pm 0.57,0.91 \pm 0.84,1.12 \pm 0.66 \mathrm{~m}$ (mean $\pm \mathrm{SD}$ ) in spring, summer and autumn, respectively. In Lake Zielone, SD decreased from 2.1 to $0.7 \mathrm{~m}$ (3-fold) after the status change from macrophyte-dominated to phytoplankton-dominated (Table 2). In Lake Gardzień, which changed its status in the opposite direction during the study, water transparency was high and similar throughout the year.

Oxygen concentration in the studied lakes ranged from 7.7 to $15.3 \mathrm{mg} \mathrm{O}_{2} \mathrm{dm}^{-3}$, $\mathrm{pH}$ values varied from 7.6 to 9.3 and conductivity fluctuated between 169 and $433 \mu \mathrm{S} \mathrm{cm}{ }^{-1}$, except Lake Zielone, where it was clearly lower $\left(82 \mu \mathrm{S} \mathrm{cm}^{-1}\right)$ (Table 2$)$. 


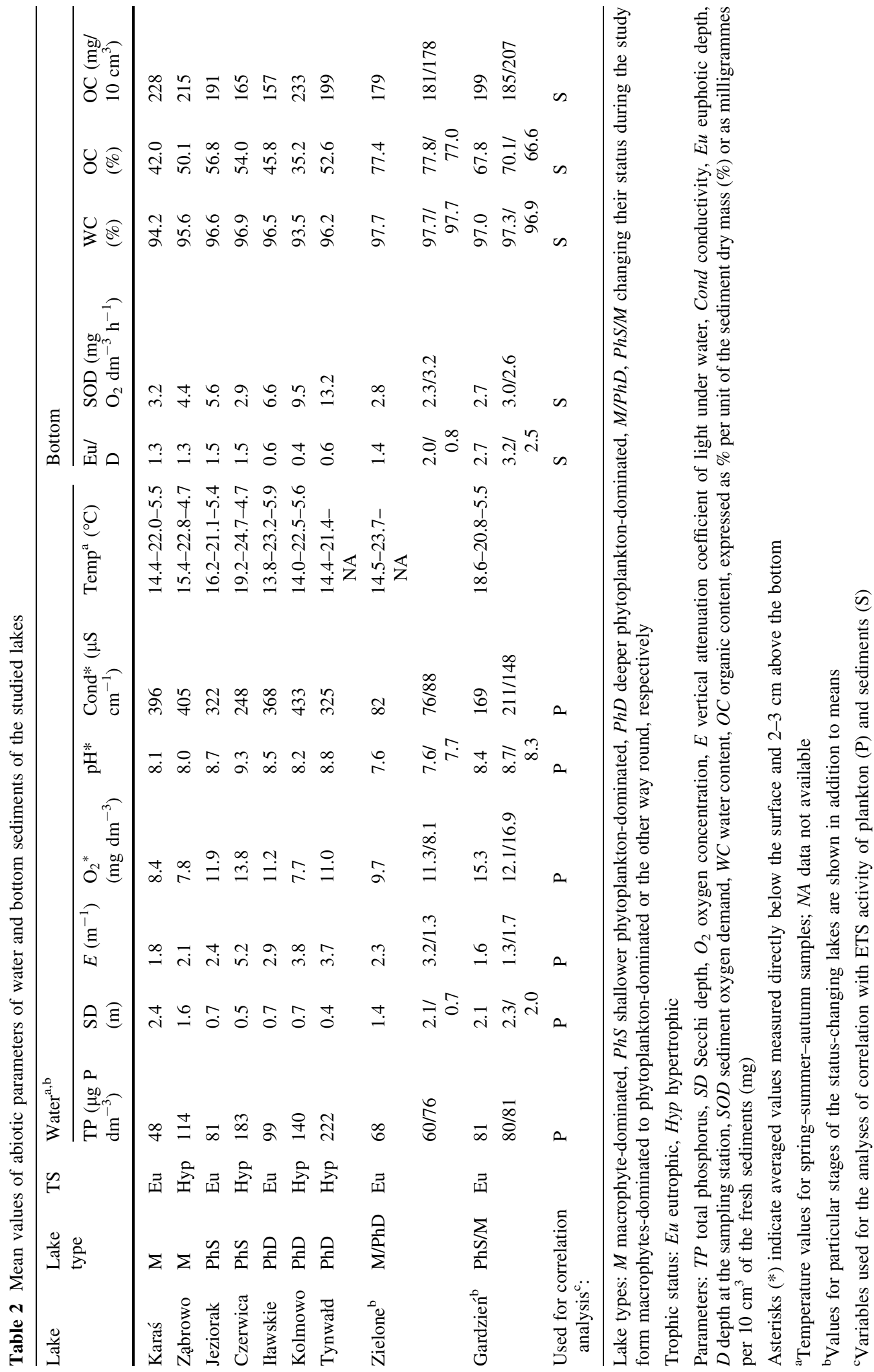


Only in the deeper phytoplankton-dominated lakes was the euphotic depth/lake depth ratio lower than 1 . SOD of the bottom sediments varied from 2.7 to $13.2 \mathrm{mg} \mathrm{O}_{2} \mathrm{dm}^{-3} \mathrm{~h}^{-1}$. Water content of the bottom sediments was relatively high, ranging from 93.5 to $97.7 \%$. The percentage of organic matter content per unit dry mass of the bottom sediments varied considerably among the studied lakes, ranging from 35.2 to $77.4 \%$. Organic matter content expressed in $\mathrm{mg}$ per $10 \mathrm{~cm}^{3}$ of the fresh bottom sediments ranged from 157 to $233 \mathrm{mg}$.

Macrophyte biomass (Supplementary Table 2) was almost four times greater in Lake Zabrowo (annual average higher than $3 \mathrm{~kg} \mathrm{~m}^{-2}$ ) than in Lake Karaś (annual average almost $0.9 \mathrm{~kg} \mathrm{~m}^{-2}$ ). Macrophyte biomasses in the status-changing lakes were much lower, but these results are not fully comparable: in Lake Zielone plants were present only in spring (status change from macrophyte-dominated into phytoplankton-dominated) and in Lake Gardzień only in summer and autumn (status changes from phytoplanktondominated into macrophyte-dominated). The greatest macrophyte biomass was noted in summer. Each lake was dominated by a different macrophyte species (Table 1).

The biomass of the bottom fauna (Supplementary Table 2) was higher in the macrophyte-dominated lakes than in the phytoplankton-dominated ones (GLM: $F_{2,3}=13.8, P=0.031$ ). This parameter was not significantly affected by season (GLM: $F_{2,6}=1.8$, $P=0.224)$ nor by its interaction with lake type (GLM: $\left.F_{4,6}=1.5, P=0.303\right)$. In most lakes, chironomid larvae (Chironomidae, Diptera) dominated the macrozoobenthos community, constituting from $60 \%$ to $90 \%$ of its total biomass. Only in the two deeper phytoplankton-dominated lakes (Kolmowo and Tynwałd), was the bottom fauna represented exclusively by Chaoborus flavicans (Chaoboridae, Diptera) larvae, whereas Zygoptera (Odonata) larvae and Oligochaeta dominated in Lake Zielone (changing its status during the study), reaching $45 \%$ and $20 \%$ of the total macrozoobenthos biomass, respectively.

\section{Respiratory carbon loss}

Respiratory carbon losses calculated on the basis of ETS activity showed that the metabolic intensity varied in different lakes (Fig. 2). The lowest value was observed in Lake Gardzień (53.3 $\mathrm{mg} \mathrm{C} \mathrm{m}^{-2} \mathrm{~h}^{-1}$ ) and the highest value (more than 4 times greater) was noted in Lake Zabrowo (241.4 $\mathrm{mg} \mathrm{C} \mathrm{m}^{-2} \mathrm{~h}^{-1}$ ). There was no clear relationship between the total RCL and lake type (Fig. 2). Lower values were observed in the status-changing lakes. In all the lakes, the highest RCL values were found in summer and the lowest values occurred in autumn.

The proportions of the microbial community, plankton, macrozoobenthos and submerged macrophytes differed among the studied lake types and seasons (Fig. 3) as shown by a significant lake type $x$ season $\mathrm{x}$ ecosystem component interaction in the GLM (Supplementary Table 3). In spring and autumn, the microorganisms in the bottom sediments contributed most to the RCL in all the lakes. In summer, macrophytes became the most important for the RCL processes in the macrophyte-dominated lakes, whereas the RCL in the other lakes was still dominated by the microorganisms in the bottom sediments.

The proportion of the plankton and macrozoobenthos in the total RCL was much lower than that of the microbial communities in the bottom sediments and macrophytes (Fig. 3). Respiratory carbon loss through plankton, assessed per water area, was relatively high in the deeper phytoplankton-dominated lakes (in all seasons) and in Lake Czerwica (in summer). The role of macrozoobenthos was most important in the macrophyte-dominated lakes in spring and autumn.

Respiratory carbon loss through the microorganisms in the bottom sediments was lowest in the macrophyte-dominated lakes and status-changing lakes, higher in the shallower phytoplankton-dominated lakes and highest in the deeper phytoplanktondominated lakes (Fig. 4). In most lakes the highest and lowest values were observed in summer and autumn, respectively. The respiratory carbon loss through the microorganisms in the bottom sediments was highly correlated with SOD $(r=0.92 ; \mathrm{df}=23 ; P<0.0001)$ and the euphotic depth/lake depth ratio $(r=-0.62$; df $=23 ; P=0.0009)$.

Respiratory carbon loss through macrophytes showed that the metabolic rate was higher in summer in the macrophyte-dominated lakes (Fig. 5). An extremely high correlation (only macrophyte-dominated lakes included, $r=0.9965 ; \mathrm{df}=7 ; P<0.0001$ ) was found between the macrophyte biomass and RCL.

Respiratory carbon loss through plankton showed that the metabolic rate per unit bottom surface area was clearly larger in the deeper phytoplankton- 
Fig. 2 Total respiratory carbon loss in the lakes under study in consecutive seasons. No samples were taken from Zielone and Tynwałd lakes in autumn. Full lake names are given in Table 1

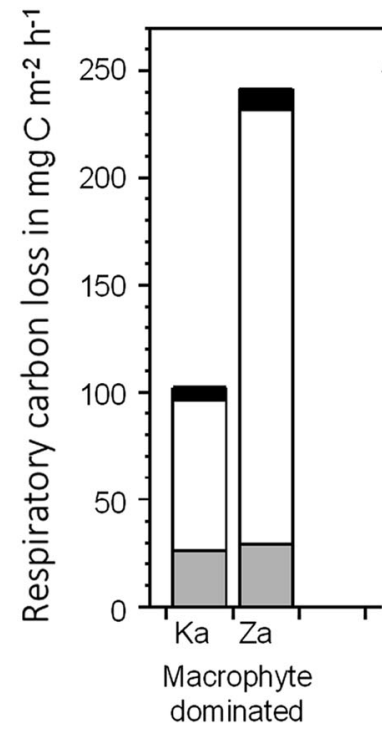

dominated lakes and in Lake Czerwica (Fig. 6A). However, as such a value depends strongly on lake depth, we also presented RCL through plankton per unit water volume (Fig. 6B), which enabled comparisons of the intensity of this process in the water column among lakes differing in depth. In this case, the highest metabolic rate through plankton was observed in Lake Czerwica, whereas the values in the other lakes were similar to one another. In all the lakes, the highest metabolic rates were found in summer. Plankton RCL per unit water volume strongly correlated $(r=0.93 ; \mathrm{df}=23 ; P<0.0001)$ with the vertical attenuation coefficient of light under water $(E)$. Moreover, a significant correlation between the plankton RCL and $\mathrm{pH} \quad(r=0.72 ; \mathrm{df}=23$; $P<0.0001)$ as well between the plankton RCL and total phosphorus $(r=0.78 ; \mathrm{df}=23 ; \quad P<0.0001)$ were observed.

Respiratory carbon loss through macrozoobenthos showed that the metabolic rate was clearly higher in the macrophyte-dominated lakes and in the statuschanging lakes than elsewhere (Fig. 7). In most lakes the highest values were found in spring. A significant correlation $(r=0.68 ; \mathrm{df}=23 ; P<0.0002)$ was found between the RCL through macrozoobenthos and the biomass of this ecosystem component.

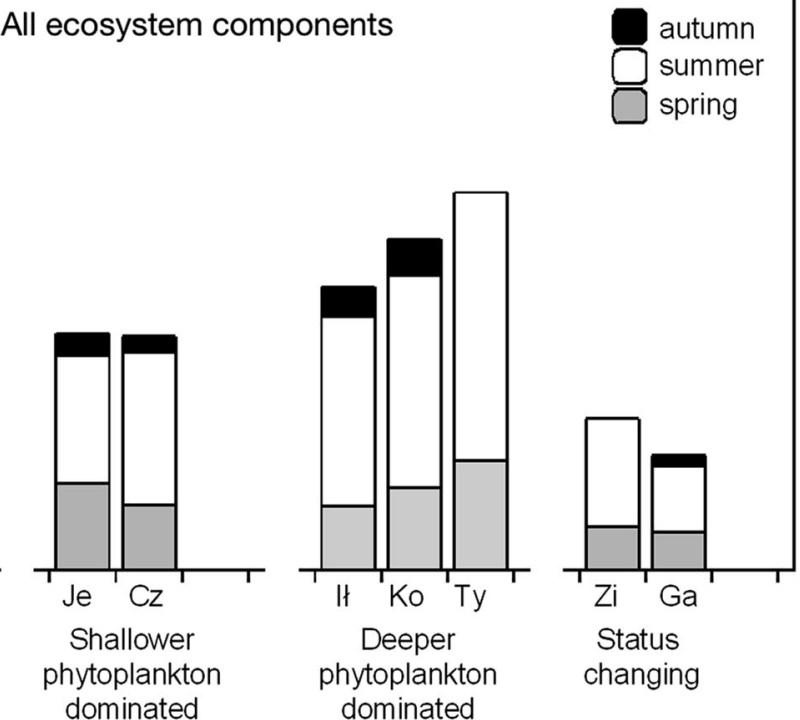

\section{Discussion}

As expected, the RCLs through the microorganisms in the bottom sediments, macrozoobenthos, plankton and macrophytes revealed their different and seasonally varying contributions to metabolic activity in various types of shallow lakes. As temperature did not vary significantly among lake types, the reasons for the differences in RCL among them must have been different. Moreover, although the spring temperature tended to be higher in shallower phytoplanktondominated lakes, it did not translate into differences in RCL. It is worth noticing that considerable differences in the absolute values of RCLs through the studied components compared with literature data available for deep and stratified lakes were also revealed.

In agreement with the findings of the previous studies (G.-Tóth, 1992; den Heyer \& Kalff, 1998; Törnblom \& Pettersson, 1998; Simčič, 2005) our results showed high RCL through the microorganisms in the sediments, which constituted a significant part of the total metabolic activity also in the shallow lakes in our study. However, it is worth noticing that the RCL through the microbial communities in the sediments was substantially higher, both as a percentage share and in absolute values, in the lakes under study than in deep (>10 m), stratified eutrophic lakes (Simčič, 2005). Nevertheless, the study by Chmiel et al. (2016) revealed that sediment organic carbon 
Fig. 3 Percentage shares of particular ecosystem components in respiratory carbon loss (assessed per unit area) in the lakes under study in consecutive seasons. Full lake names are given in Table 1

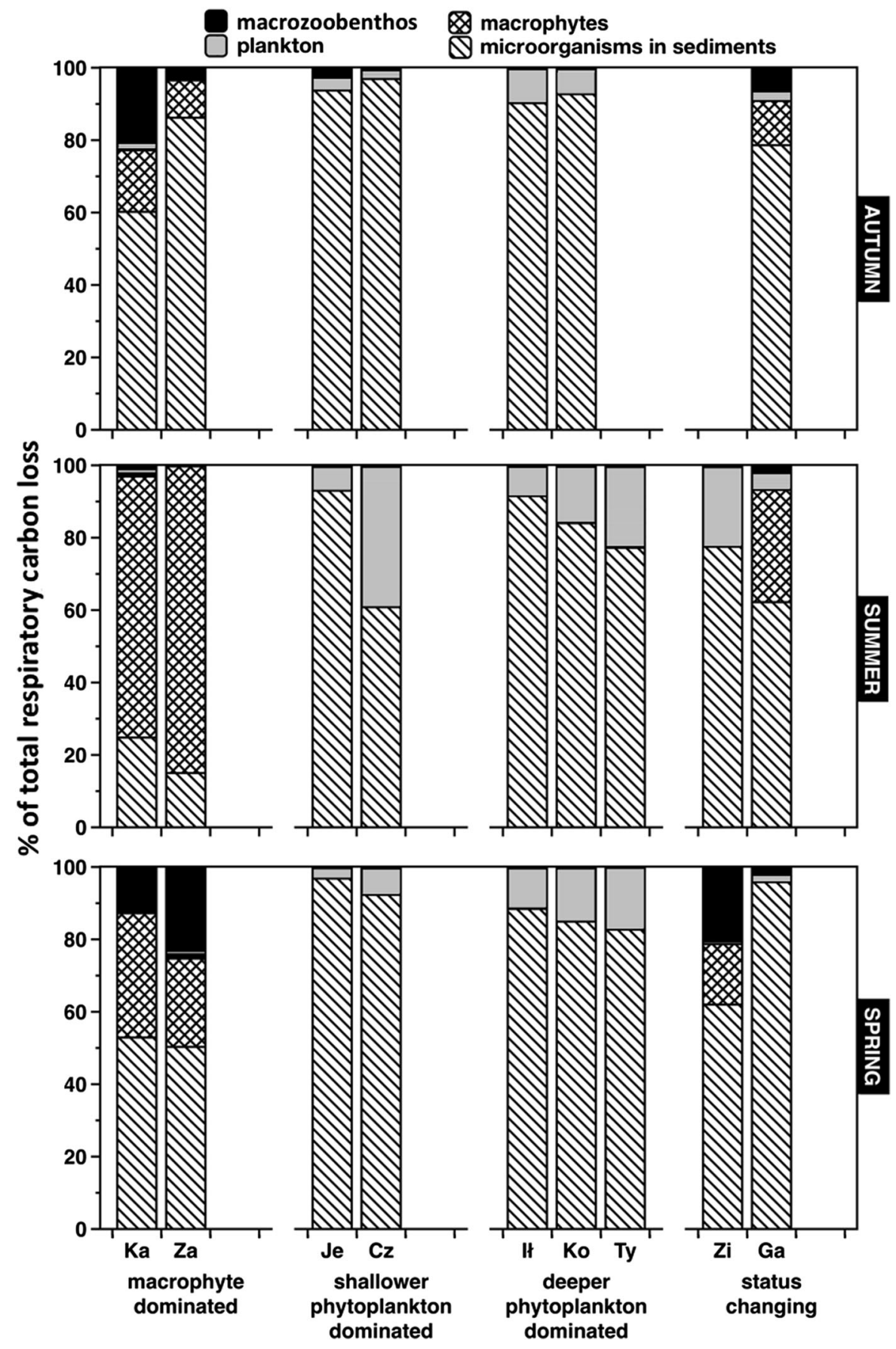

mineralization contributed a comparatively small share $(16 \%)$ to the $\mathrm{CO}_{2}$ emission in a shallow humic boreal lake. They assume that the importance of sediments for the carbon budget of boreal lakes probably vary depending on basin morphometry (sediment area-to-water volume ratio), stratification patterns and, as a consequence, temperature and oxygen regimes.

Electron Transport System (ETS) activity of bottom sediments is a measure of the respiratory activity of bacteria (Muri \& Simčič, 2004), as it is mainly based on bacterial activity (Törnblom \& Pettersson, 
Fig. 4 Respiratory carbon loss through the microorganisms in the bottom sediments in the lakes under study in consecutive seasons. No samples were taken from Zielone and Tynwałd lakes in autumn. Full lake names are given in Table 1
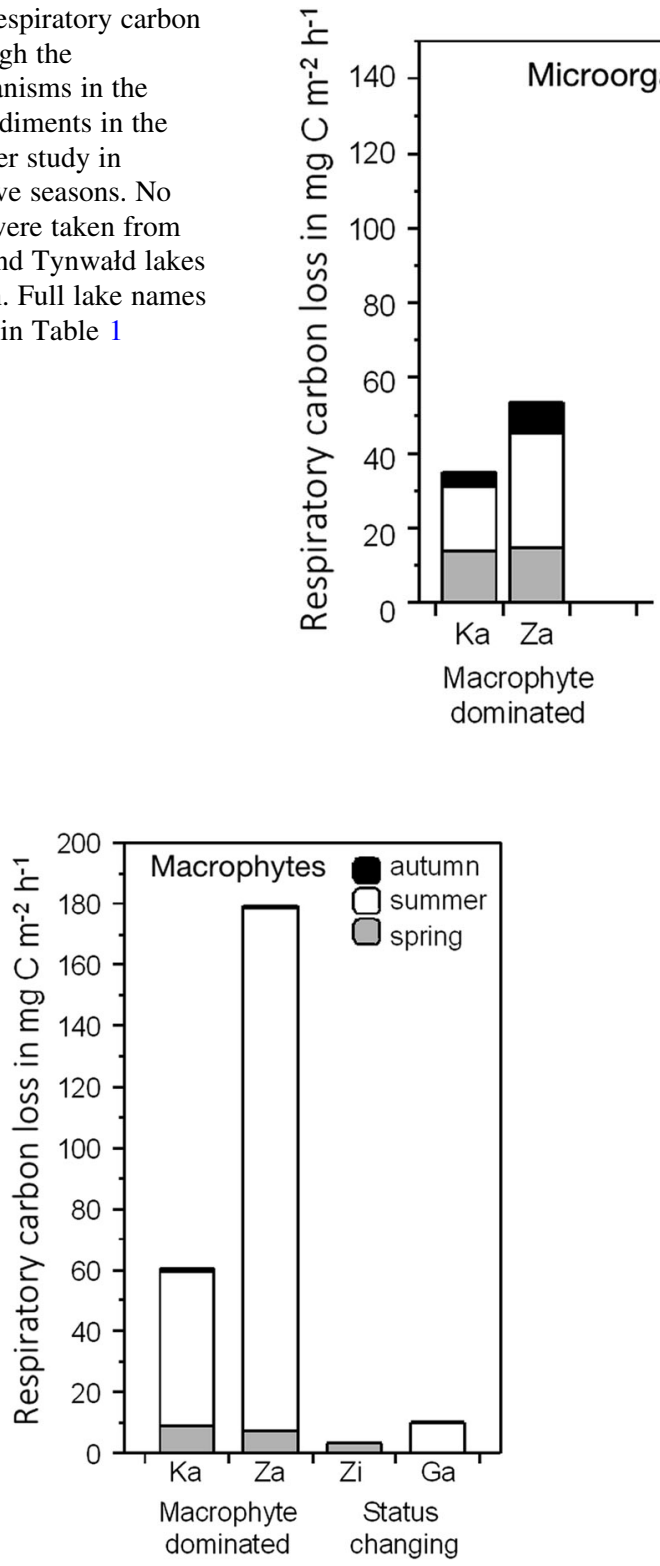

Fig. 5 Respiratory carbon loss through macrophytes in macrophyte-dominated (Ka, Za) and status-changing ( $\mathrm{Zi}, \mathrm{Ga}$ ) lakes in consecutive seasons. No samples were taken from Zielone Lake in autumn. Full lake names are given in Table 1

1998). However, in shallow lakes, microphytobenthos can additionally contribute to the respiratory activity of microorganisms in the sediments. These organisms are able to survive and photosynthesize even under extremely low light conditions, as evidenced by McGee et al. (2008) for benthic diatoms. Moreover, mixotrophic diatoms switch their metabolism from
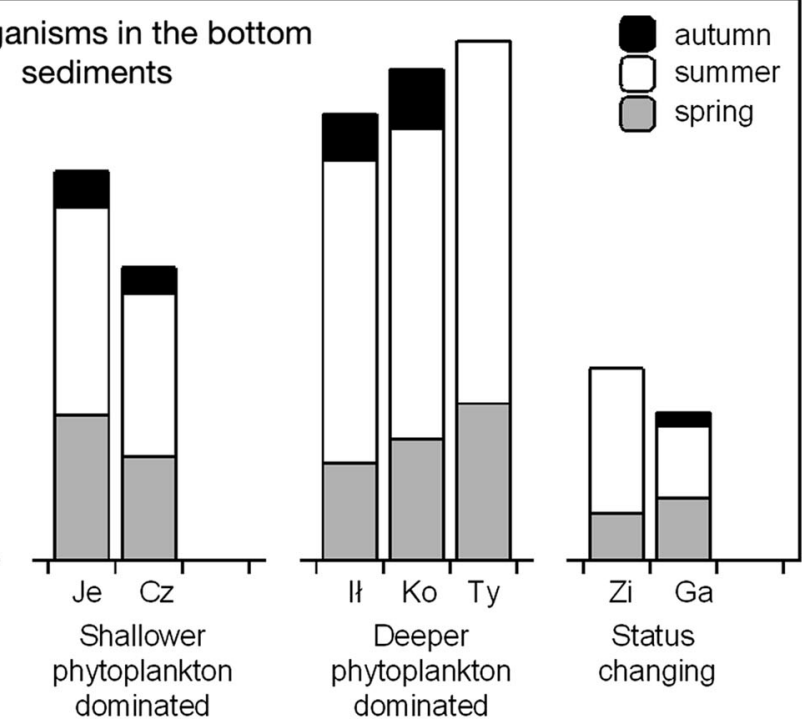

Status changing

photoautotrophic to heterotrophic when light levels are too low for photosynthesis and can contribute to respiratory activity in the sediments (Tuchman et al., 2006). In our study only in the deeper phytoplanktondominated lakes was the euphotic depth/lake depth ratio lower than 1, indicating that the light intensity at the bottom might be insufficient to sustain the growth of microphytobenthos. However, taking into account the above information, it is likely that microphytobenthos contributed to RCL in the bottom sediments even in those lakes. Nevertheless, we did not study microphytobenthos directly, thus we cannot confirm this assumption.

In the deep, stratified and eutrophic lakes mentioned above, low temperatures and oxygen depletions (6-8\% of oxygen saturation) were observed at the bottom in summer (Simčič, 2005), and both these abiotic factors are likely to restrict the metabolic activity of bacteria as well as the rate of mineralization (Kristensen et al., 1985). The decreasing bacterial production and total sediment metabolism that coincided with the decreasing sediment redox potential in summer was also evidenced by Törnblom \& Pettersson (1998) and Germ \& Simčič (2011). In the present study, a positive, significant correlation between the RCL through the microorganisms in the bottom sediments and SOD also indicated a relationship between the intensity of mineralization of organic matter and dissolved oxygen concentration of the overlying water. However, in contrast to deep, 
Fig. 6 Respiratory carbon loss through plankton per unit surface (water column under unit area) (A) and per unit water volume $(\mathbf{B})$ in the lakes under study in consecutive seasons. No samples were taken from Zielone and Tynwałd lakes in autumn. Full lake names are given in Table 1
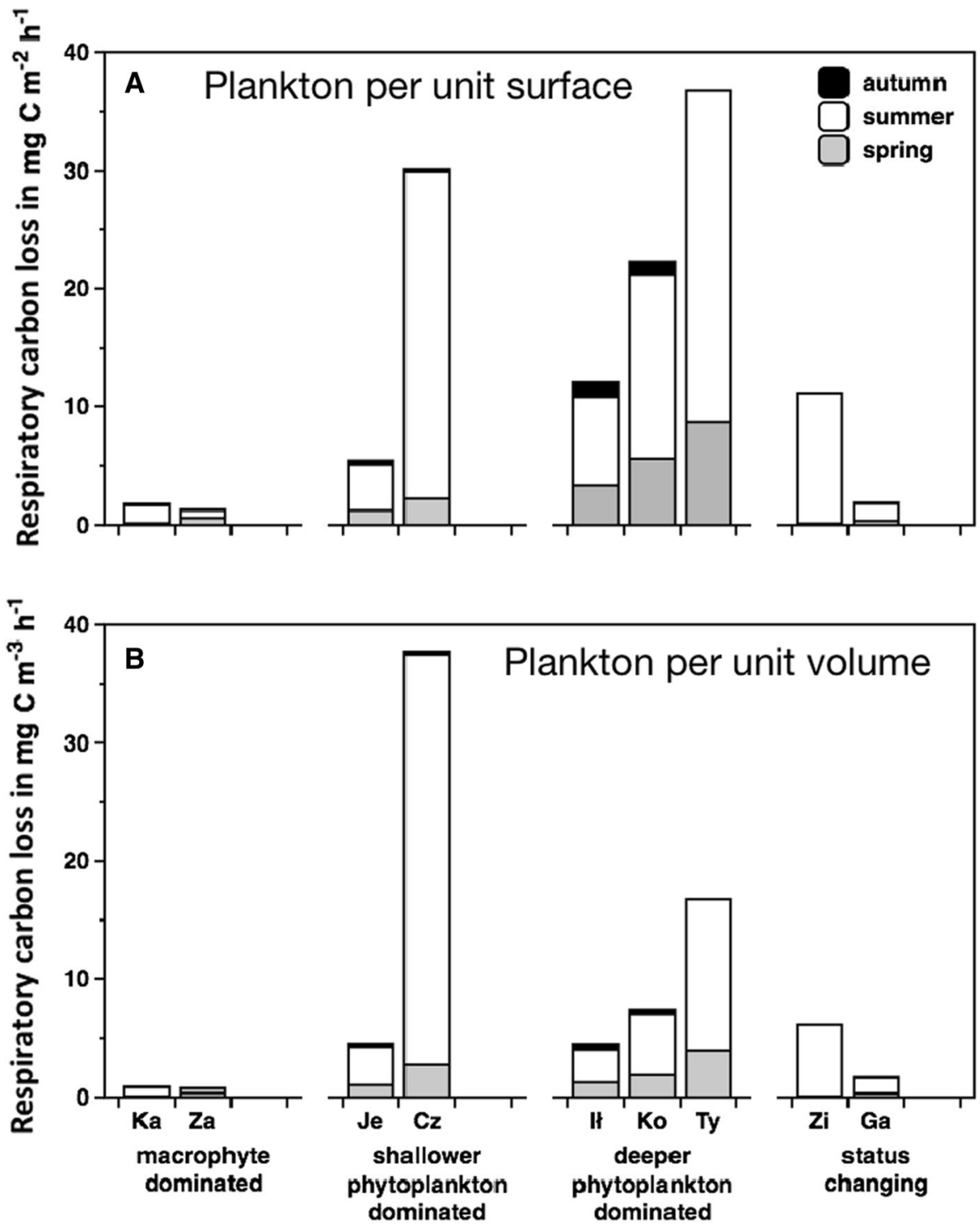

stratified eutrophic lakes (Simčič, 2005), oxygen concentrations and water temperatures at the bottom during the vegetation season remained relatively high in all the studied lakes, enabling faster organic matter mineralization at their bottom. The reason is their shallow depth, which enables mixing of the whole water column, including a layer above the sediment surface, providing a suitable environment for microbial respiration in the sediments. Moreover, the role of oxygen and dissolved organic carbon availability in controlling nutrient release from the sediments of a shallow, polymictic Australian lake was also evidenced by Müller et al. (2016).
The present study revealed that the RCL through microorganisms in sediments differed among various lake types of the same trophic status. The higher RCL through the microorganisms in sediments of the phytoplankton-dominated lakes indicated more intense mineralization of organic matter compared with the macrophyte-dominated lakes and statuschanging lakes during the presence of macrophytes. The respiratory activity in the sediments was reported to be affected by the amount and origin of organic matter and temperature (de Vicente et al., 2010; Germ $\&$ Simčič, 2011). However, in the present study the temperature could not be the reason for the observed 
Fig. 7 Respiratory carbon loss through zoobenthos in the lakes under study in consecutive seasons. No samples were taken from Zielone and Tynwałd lakes in autumn. Full lake names are given in Table 1

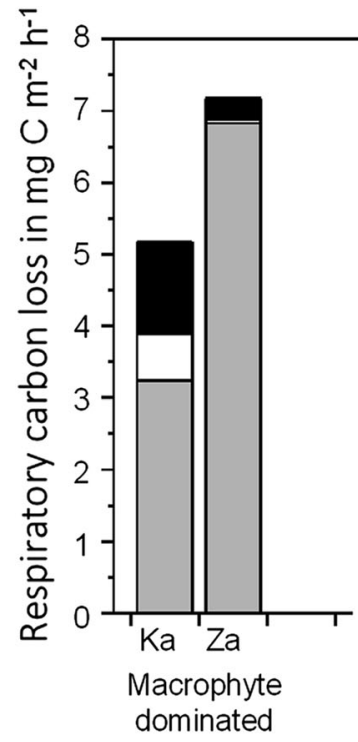

differences, as water temperature was similar in both macrophyte-dominated and phytoplankton-dominated lakes or in some cases even lower in the latter. However, it is well known that phytoplankton detritus is labile and easily degradable, while vascular plant remains are structurally complex and therefore a longer period is needed to degrade them to forms that can be easily decomposed further by bacteria (Kristensen et al., 1995). In our study, a large amount of labile organic matter accumulated on the surface of the sediments of the phytoplankton-dominated lakes represented a better growth medium for heterotrophic bacteria. This enabled a more intensive mineralization of organic matter compared with the macrophytedominated lakes. Similarly, Brothers et al. (2013) found higher respiration in the sediments of the phytoplankton-dominated shallow eutrophic Lake Gollinsee than in the sediments of the macrophytedominated shallow eutrophic Lake Schulzensee. Interestingly, Algesten et al. (2005) reported that sediments contributed little to the total production and emission of $\mathrm{CO}_{2}$ in boreal and subarctic lakes of low productivity during a typical summer because the source of $\mathrm{CO}_{2}$ production is mineralization of allochthonous carbon in its dissolved form which never reaches the lake sediments even in shallow lakes. Moreover, a lower benthic respiration (28.1-237.1 $\mathrm{mg} \mathrm{C} \mathrm{m}^{-2} \mathrm{day}^{-1}$ ) compared to the rates from our study (from $416 \mathrm{mg} \mathrm{C} \mathrm{m}^{-2}$ day $^{-1}$ in Karaś

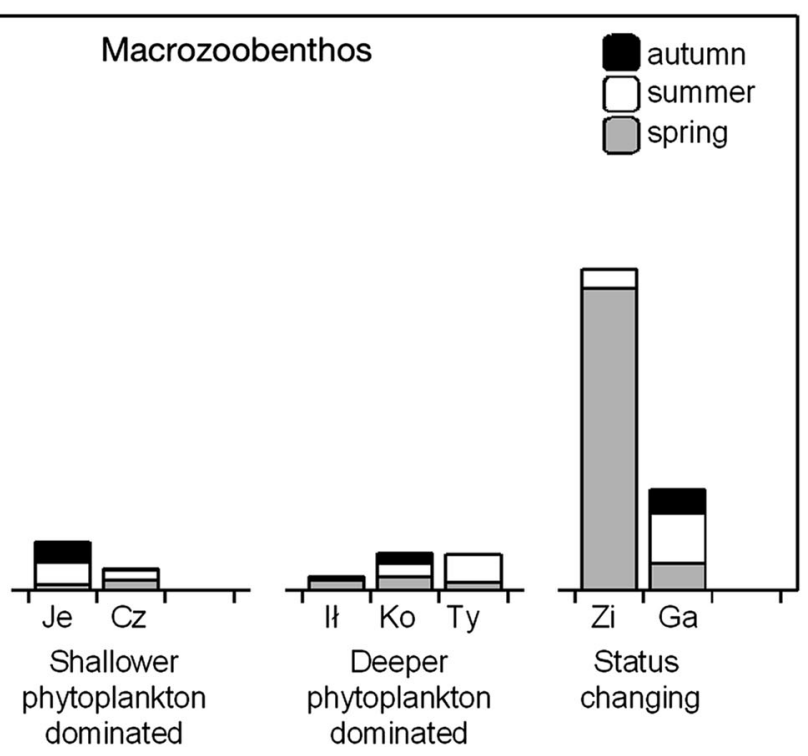

to $2324 \mathrm{mg} \mathrm{C} \mathrm{m}^{-2}$ day $^{-1}$ in Tynwałd in summer) was recorded in 15 small, shallow unproductive boreal or alpine lakes in northern Sweden (Ask et al., 2012). However, we can conclude that the carbon and nutrient cycling in shallow, highly productive, especially phytoplankton-dominated lakes is driven by the rapid degradation and mineralization of the labile autochthonous organic matter.

The microbial communities in the sediments in all studied types of lakes contributed to the largest extent to the total RCL in spring and autumn, while in summer the massive presence of submerged plants in the macrophyte-dominated lakes led to the high areal RCL through macrophytes, as well as to their high contribution to the total areal RCL. The respiratory carbon loss through macrophytes was highly correlated with their biomass, regardless of their taxonomic composition. This indicates that the dominant macrophyte species had similar mass-specific metabolic activity. Extremely high respiration of macrophytes in summer, apart from being correlated with higher water temperature, is also related to additional energy requirements during their intensive growth and development in order to build structural components (Germ \& Simčič, 2011). In previous studies, it was shown that the high productivity and biomass turnover of macrophytes in fertile ecosystems, similar to Lakes Zạbrowo and Karaś in the present study, contributed to the high rates of nutrient mobilization from the sediments 
(Smith \& Adams, 1986; Kleeberg et al., 2010; Camacho et al., 2016). Brothers et al. (2013) also found that macrophytes considerably contributed to the total carbon loss in the macrophyte-dominated shallow eutrophic lake. In contrast to the shallow eutrophic lakes, significantly lower values of the macrophyte RCL, up to $0.4 \mathrm{mg} \mathrm{C} \mathrm{m}^{-2} \mathrm{~h}^{-1}$ in summer, was observed in the littoral of the deep, oligotrophic Lake Bohinj (Simčič \& Germ, 2009), despite similar biomasses of macrophytes in the compared lakes. For comparison, Martinsen et al. (2017) who studied ecosystem metabolism in five small, shallow, oligotrophic lakes dominated by charophytes on the nutrient poor plains of Öland (Sweden) found high rates of production and respiration during springsummer period as a result of the high charophyte biomass and shallow mixed surface layer. Thus, it is suggested that the macrophytes have an essential role in the cycling of carbon and nutrients in shallow, highly productive lakes.

As expected, the percentage shares of plankton in the total RCL in the lakes being studied were very low, with the exception of the deeper phytoplanktondominated lakes, where relatively high values were found due to the higher water depth (larger water volume) and high abundance of algae. Theoretically, the considerable role of plankton in these lakes could have been exaggerated by overestimation of its abundance due to collecting samples from the $0.5-\mathrm{m}$ surface water layer. However, high dynamics of water (as a consequence of wind action) was noted in the studied deeper phytoplankton-dominated lakes (minor differences between surface and near-bottom temperatures) resulting in the lack of vertical stratification. It is the consequence of a good exposure of the studied lakes to wind (Table 1). Therefore, it can be assumed that plankton was evenly distributed in the entire water column of the studied lakes. On the other hand, in the macrophyte-dominated lakes and the status-changing one after its switch to macrophyte domination the phytoplankton abundances were very low due to the presence of submerged plants and their mechanisms limiting phytoplankton growth (Scheffer, 1998). It is worth mentioning that the RCL through plankton in summer in Lake Czerwica was relatively high. The explanation is the very high total phosphorus concentration in water, which in conjunction with high temperature and good light conditions (the shallowest lake) provided a favourable environment for the intensive phytoplankton development in the whole water column. Thus, plankton can be a crucial biocoenotic element in the RCL in summer even in a very shallow lake provided that it is dominated by phytoplankton.

For the lakes with phytoplankton domination the differences were observed in the RCL through plankton per unit surface area as well as per unit water volume among lakes of various trophic status and depth. For example, within the shallower phytoplankton-dominated lakes, considerably higher RCL through plankton was observed in the hypertrophic Lake Czerwica than in the eutrophic Lake Jeziorak. Similarly, among the deeper phytoplankton-dominated lakes, total phosphorus concentration was positively correlated with RCL through plankton. Higher metabolic activity of plankton, noted in the lakes with higher trophic level are in accord with the findings of G.-Tóth (1992), who found higher plankton ETS activity in the hypertrophic Keszthely-basin $\left(179.3 \mathrm{~cm}^{3} \mathrm{O}_{2} \mathrm{~m}^{-2} \mathrm{~h}^{-1}\right)$ than in the meso-eutrophic Siófok-basin $\left(58.3 \mathrm{~cm}^{3} \mathrm{O}_{2} \mathrm{~m}^{-2} \mathrm{~h}^{-1}\right)$ of Lake Balaton. Significant correlation between total phosphorus concentration and pelagic respiration was also reported for late summer-autumn in small, shallow seepage lakes located in nutrient-rich, calcareous moraine soils in North Zealand (Denmark) (Sand-Jensen \& Staehr, 2007).

Calculation of RCL per unit surface area of a lake is sufficient to assess the role of plankton in this process relative to the other biocoenotic elements. However, it can be assumed that in deeper lakes the role of plankton in the metabolism of organic matter should be greater than in shallow ones, due to the greater abundance of plankton in the entire water column in the former. Thus, to compare the intensity of RCL only through plankton in lakes of various depth, a recalculation per unit volume should be made. That is why in the present paper both approaches are presented, showing a difference in the case of the shallowest Lake Czerwica, where the intensity of RCL through plankton calculated per unit volume was the highest among the studied lakes, whereas the values calculated per unit surface area were similar in Lake Czerwica and in one of the deeper phytoplankton-dominated lakes (Tynwałd).

As for the sediments of deep, stratified lakes, much lower values of RCL through plankton (more than 10-fold), up to $2 \mathrm{mg} \mathrm{C} \mathrm{m}^{-2} \mathrm{~h}^{-1}$ or $0.2 \mathrm{mg} \mathrm{C} \mathrm{m}^{-3} \mathrm{~h}^{-1}$, 
were also reported from deep, stratified eutrophic lakes (Simčič, 2005) compared to the studied shallow ones. The differences are likely to result from higher temperatures and better light conditions in most of the water column and greater availability of nutrients for phytoplankton due to the lack of thermal stratification in the shallow lakes, compared to deep, stratified ones. Interestingly, relatively high pelagic respiration rates (27.4-546.0 mg C m${ }^{-2} \mathrm{day}^{-1}$ ) were reported for small, unproductive Swedish lakes (Ask et al., 2012), compared to the RCL through plankton in lakes from our study, in which RCL varied from $15 \mathrm{mg} \mathrm{C} \mathrm{m}^{-2}$ day $^{-1}$ in Zabrowo to $676 \mathrm{mg} \mathrm{C} \mathrm{m}^{-2}$ day $^{-1}$ in Tynwałd.

Since the respiration rate of organisms increases with the higher environmental temperature (Törnblom \& Pettersson, 1998; Simčič \& Germ, 2009; Laas et al., 2012), the highest RCL through almost all studied elements of the biocoenosis was observed in summer and the lowest values were measured in autumn, except for the macrozoobenthos component in the macrophyte-dominated lakes and the status-changing Lake Zielone before a regime shift, where the highest values were obtained in spring. The main reason for the lower RCL through macrozoobenthos in summer is its lower abundance rather than lower metabolic activity, as our results revealed a significant correlation between the RCL through macrozoobenthos and the biomass of this ecosystem component. The lower abundance of macrozoobenthos in summer was probably caused by the increased predation by fish (Gerking, 1994), resulting from higher water temperature increasing fish metabolic rate and thus stimulating their foraging. Moreover, emerging insects could also reduce the abundance of macrozoobenthos in summer (Armitage et al., 1995). Relatively high RCL through macrozoobenthos in the macrophyte-dominated lakes and the status-changing lakes during their macrophyte-dominated state (Lake Zielone in spring and Lake Gardzień in summer) indicated the relatively important role of that component in the metabolism of organic matter, which was exclusive for this lake type. Nevertheless, the role of zoobenthos in these lakes was still lower than that of the microorganisms in the sediments and macrophytes, The results of our study are in accord with those of Brothers et al. (2013), who found lower carbon losses through macrozoobenthos in a phytoplankton-dominated lake $\left(0.9 \mathrm{mg} \mathrm{C} \mathrm{m}^{-2}\right.$ $\mathrm{h}^{-1}$ ) in comparison to a lake with macrophyte domination (3.1 mg C m $\mathrm{m}^{-2} \mathrm{~h}^{-1}$ ). Moreover, RCL through macrozoobenthos found in our study was similar to that observed by Brothers et al. (2013) in a shallow, eutrophic, macrophyte-dominated lake, but substantially higher than in deep, stratified eutrophic lakes, where the values below $0.1 \mathrm{mg} \mathrm{C} \mathrm{m}^{-2} \mathrm{~h}^{-1}$ were reported (Simčič, 2005).

Interestingly, the lowest total RCL was observed in the two status-changing lakes. This was due to the relatively low mineralization rate at the bottom, which also confirms the lowest $\mathrm{SOD}\left(<3 \mathrm{mg} \mathrm{O}_{2} \mathrm{dm}^{-3} \mathrm{~h}^{-1}\right)$ in the status-changing lakes, and in the water column, resulting from the relatively small amount of detritus reaching the bottom and low phytoplankton abundance, respectively (transparent water). Moreover, the biomass of macrophytes in the status-changing lakes was relatively small compared to the lakes dominated by macrophytes throughout the year.

An interesting issue is the alternative status change that took place during our study in two of the lakes: Lake Gardzień that turned from a phytoplanktondominated status into a macrophytes-dominated status and Lake Zielone that changed in the opposite direction. Factors inducing alternative status changes have been comprehensively discussed by Scheffer (1998). However, in this particular case it is difficult to find a definitive cause of the observed phenomenon. We did not observe any changes in the lake watersheds, their use and/or chemical regimes. Despite the relatively short distance between the two lakes (ca. $15 \mathrm{~km}$ in straight line), they changed in the opposite directions, which suggests the importance of local factors. On the other hand, taking the unique character of particular lakes into account, we cannot exclude that the same factor induced different changes in each of them. Anyway, further detailed studies on lakes and their watersheds are needed to determine exact mechanisms of the phenomenon of alternative status changes.

\section{Conclusions}

The role of particular components in the total RCL varied with the type of a shallow lake and season. High carbon losses through respiration of microbial communities in sediments, especially in phytoplanktondominated lakes, contributed substantially to the mineralization of organic matter and recycling of 
carbon and nutrients in shallow lakes of a high trophic level. The respiratory carbon loss through the studied organisms was the highest in summer with the exception of benthic macroinvertebrates due to their very low biomass at the time. Moreover, high RCL through macrophytes in macrophyte-dominated lakes during the vegetation period confirmed the importance of vascular plants for the functioning of shallow lakes. Plankton respiration per unit water volume did not differ between both types of phytoplankton-dominated lakes, which resulted in the higher impact of this component in deeper lakes. It is therefore suggested that the shallow, highly eutrophic lakes can be extremely productive ecosystems due to intensive mineralization of organic matter at the bottom and rapid flow and cycling of carbon and nutrients due to their polymictic character. The observed strong correlations between SOD, macrophyte biomass, vertical attenuation coefficient of light under water and RCL through microbial communities in sediments, macrophytes and plankton, respectively, suggest that these parameters could be considered as good predictors of RCL in shallow lakes.

Acknowledgements This study was financially supported by the Slovenian Research Agency (Project BI-PL/10-11-008 and Research Program P1-0255) and internal funds of Nicolaus Copernicus University in Toruń, Poland. We are grateful to Dr Maciej Operacz for conducting the total phosphorus measurements. We are also very grateful to anonymous reviewers for all their comments and suggestions and to Mrs Hazel Pearson for correcting the English language, which undoubtedly contributed to improving the quality of this publication.

Open Access This article is distributed under the terms of the Creative Commons Attribution 4.0 International License (http:// creativecommons.org/licenses/by/4.0/), which permits unrestricted use, distribution, and reproduction in any medium, provided you give appropriate credit to the original author(s) and the source, provide a link to the Creative Commons license, and indicate if changes were made.

\section{References}

Åberg, J., A. K. Bergström, G. Algesten, K. Söderback \& M. Jansson, 2004. Comparison of the carbon balances of a natural lake (L. Örträsket) and a hydroelectric reservior (L. Skinnmuddselet) in northern Sweden. Water Research 38: 531-538.

Algesten, G., S. Sobek, A.-K. Bergström, A. Jonsson, L. J. Tranvik \& M. Jansson, 2005. Contribution of sediment respiration to summer $\mathrm{CO}_{2}$ emission from low productive boreal and subarctic lakes. Microbial Ecology 50: 529-535.

Armitage, P. D., P. S. Cranston \& L. C. V. Pinder, 1995. The Chironomidae. Biology and Ecology of Non-biting Midges. Chapman \& Hall, London: 572.

Ask, J., J. Karlsson \& M. Jansson, 2012. Net ecosystem production in clear-water and brown-water lakes. Global Biogeochemical Cycles 26: GB1017.

Bamstedt, U., 1980. ETS activity as an estimator of respiratory rate of zooplankton populations. The significance of variations in environmental factors. Journal of Experimental Marine Biology and Ecology 42: 267-283.

Brothers, S. M., S. Hilt, K. Attermeyer, H. P. Grossart, S. Kosten, B. Lischke, T. Mehner, N. Meyer, K. Scharnweber \& J. Köhler, 2013. A regime shift from macrophyte to phytoplankton dominance enhances carbon burial in a shallow, eutrophic lake. Ecosphere 4: 137.

Camacho, A., N. Murueta, E. Blasco, A. C. Santamans \& A. Picazo, 2016. Hydrology-driven macrophyte dynamics determines the ecological functioning of a model Mediterranean temporary lake. Hydrobiologia 774: 93-107.

Chmiel, H. E., J. Kokic, B. A. Denfeld, K. Einarsdóttir, M. B. Wallin, B. Koehler, A. Isidorova, D. Bastviken, M. È. Ferland \& S. Sobek, 2016. The role of sediments in the carbon budget of a small boreal lake. Limnology and Oceanography 61: 1814-1825.

Daniels, W. C., G. W. Kling \& A. E. Giblin, 2015. Benthic community metabolism in deep and shallow Arctic lakes during 13 years of whole-lake fertilization. Limnology and Oceanography 60: 1604-1618.

de Vicente, I., V. Amores \& L. Cruz-Pizarro, 2006. Instability of shallow lakes: a matter of the complexity of factors involved in sediment and water interaction? Limnetica 25 : 253-270.

de Vicente, I., V. Amores, F. Guerrero \& L. Cruz-Pizarro, 2010. Contrasting factors controlling microbial respiratory activity in the sediment of two adjacent Mediterranean wetlands. Naturwissenschaften 97: 627-635.

del Giorgio, P. A., 1992. The relationship between ETS (electron transport system) activity and oxygen consumption in lake plankton: a cross-system calibration. Journal of Plankton Research 14: 1723-1741.

den Heyer, C. \& J. Kalff, 1998. Organic matter mineralization rates in sediments: a within- and among-lake study. Limnology and Oceanography 43: 695-705.

Devol, A. H., 1979. Zooplankton respiration and its relation to plankton dynamics in two lake of contrasting trophic state. Limnology and Oceanography 24: 893-905.

Devol, A. H. \& T. T. Packard, 1978. Seasonal changes in respiratory enzyme activity and productivity in Lake Washington microplankton. Limnology and Oceanography 23: 104-117.

Filbrun, J. E., J. D. Conroy \& Da Culver, 2013. Understanding seasonal phosphorus dynamics to guide effective management of shallow, hypereutrophic Grand Lake St. Marys, Ohio. Lake and Reservoir Management 29: 165-178.

Gerking, S. D., 1994. Feeding Ecology of Fish. Academic Press, San Diego: 416 pp. 
Germ, M. \& T. Simčič, 2011. Vitality of aquatic plants and microbial activity of sediment in an oligotrophic lake (Lake Bohinj, Slovenia). Journal of Limnology 70: 305-312.

G.-Tóth, L., 1992. Respiratory electron transport system activity (ETS) - activity of the plankton and sediment in Lake Balaton (Hungary). Hydrobiologia 243(244): 157-166.

G.-Tóth, L., 1999. Aktivität des Elektronentransportsystems. In von Tümpling, W. \& G. Friedrich (eds), Biologische Gewässeruntersuchung. Methoden der Biologischen Wasseruntersuchung 2, Gustav Fischer Verlag, Jena: 465-473.

G.-Tóth, L., Zs Lango, J. Padisak \& E. Varga, 1994. Terminal electron transport system (ETS) - activity in the sediment of Lake Balaton, Hungary. Hydrobiologia 281: 129-139.

G.-Tóth, L., P. Carrillo \& L. Cruz-Pizarro, 1995. Respiratory electron transport system (ETS) - activity of the plankton and biofilm in the high-mountain Lake La Caldera (Sierra Nevada, Spain). Archiv für Hydrobiologie 135: 65-78.

Hakanson, L. \& M. Jansson, 1983. Principles of Lake Sedimentology. Springer, Heidelberg: 316 pp.

Hernández-León, S., M. Gómez, M. Pagazaurtundua, A. Portillo-Hahnefeld, I. Montero \& C. Almeida, 2001. Vertical distribution of zooplankton in Canary Island waters: implications for export flux. Deep Sea Research 48: 1071-1092.

James, M. R., 1987. Respiratory rates in cladoceran Ceriodaphnia dubia in Lake Rotiongaio, a monomictic lake. Journal of Plankton Research 9: 573-578.

Jensen, H. S. \& F. O. Andersen, 1992. Importance of temperature, nitrate, and $\mathrm{pH}$ for phosphate release from aerobic sediments of four shallow, eutrophic lakes. Limnology and Oceanography 37: 577-589.

Jónasson, P. M., C. Lindegaard \& K. Hamburger, 1990. Energy budget of Lake Esrom. Verhandlungen Internationale Vereinigung für Limnologie 24: 632-640.

Jonsson, A., M. Meili, A.-K. Bergström \& M. Jansson, 2001. Whole-lake mineralization of allochthonous and authothonous carbon in a large humic lake (Örträsket, N. Sweden). Limnology and Oceanography 46: 1691-1700.

Kenner, R. A. \& S. I. Ahmed, 1975a. Correlation between oxygen utilization and electron transport activity in marine phytoplankton. Marine Biology 33: 129-133.

Kenner, R. A. \& S. I. Ahmed, 1975b. Measurements of electron transport activities in marine phytoplankton. Marine Biology 33: 119-127.

Kleeberg, A., C. Herzog, S. Jordan \& M. Hupfer, 2010. What drives the evolution of the sedimentary phosphorus cycle? Limnologica 40(Sp. Iss. SI), 102-113.

Kominoski, J. S., A. D. Rosemond, J. P. Benstead, V. Gulis \& D. W. P. Manning, 2018. Experimental nitrogen and phosphorus additions increase rates of stream ecosystem respiration and carbon loss. Limnology and Oceanography 63: 22-36.

Krausz, E., J. Vallner \& J. L. Halász, 2012. Sediment studies in Hungarian surface waters. European Chemical Bulletin 1: 540-543.

Kristensen, E., M. H. Jensen \& T. K. Andersen, 1985. The impact of polychaeta (Nereis virens Sars) burrows on nitrification and nitrate reduction in estuarine sediments.
Journal of Experimental Marine Biology and Ecology 85: 75-91.

Kristensen, E., R. I. Ahmed \& A. H. Devol, 1995. Aerobic and anaerobic decomposition of organic matter in marine sediment: which is fastest? Limnology and Oceanography 40: $1430-1437$.

Kurashov, E. A., 2002. The role of meiobenthos in lake ecosystems. Aquatic Ecology 36: 447-463.

Laas, A., P. Nõges, T. Kõiv \& T. Nõges, 2012. High-frequency metabolism study in a large and shallow temperate lake reveals seasonal switching between net autotrophy and net heterotrophy. Hydrobiologia 694: 57-74.

Lampert, W., 1984. The measurement of respiration. In Downing, J. A. \& F. H. Rigler (eds), A Manual on Methods for the Assessment of Secondary Productivity in Fresh Water. IPB Handbook 17, 2nd edn. Blackwell, Oxford: 413-468.

Lewandowski, J., I. Schauser \& M. Hupfer, 2003. Long terms effects of phosphorus precipitations with alum in hypereutrophic Lake Süsser See (Germany). Water Research 37: 3194-3204.

Lindegaard, C., 1994. The role of zoobenthos in energy flow in two shallow lakes. Hydrobiologia 275(276): 313-322.

Lischke, B., T. Mehner, S. Hilt, K. Attermeyer, M. Brauns, S. Brothers, H.-P. Grossart, J. Köhler, K. Scharnweber \& U. Gaedke, 2017. Benthic carbon is inefficiently transferred in the food webs of two eutrophic shallow lakes. Freshwater Biology 62: 1693-1706.

Martinsen, K. T., M. R. Andersen, T. Kragh \& K. Sand-Jensen, 2017. High rates and close diel coupling of primary production and ecosystem respiration in small, oligotrophic lakes. Aquatic Sciences 79: 995-1007.

McGee, D., R. A. Laws \& L. B. Cahoon, 2008. Live benthic diatoms from the upper continental slope: extending the limits of marine primary production. Marine Ecology Progress Series 356: 103-112.

McKinnon, A. D., J. Doyle, S. Duggan, M. Logan, C. Lønborg \& R. Brinkman, 2015. Zooplankton growth, respiration and grazing on the Australian margins of the tropical Indian and Pacific Oceans. PLoS ONE 10(10): e0140012.

Moreira, A., E. Figueira, I. L. Pecora, A. M. V. M. Soares \& R. Freitas, 2017. Biochemical alterations in native and exotic oyster species in Brazil in response to increasing temperature. Comparative Biochemistry and Physiology, Part C 191: 183-193.

Müller, S., S. M. Mitrovic \& D. S. Baldwin, 2016. Oxygen and dissolved organic carbon control release of $\mathrm{N}, \mathrm{P}$ and $\mathrm{Fe}$ from the sediments of a shallow, polymictic lake. Journal of Soils and Sediments 16: 1109-1120.

Muri, G. \& T. Simcic, 2004. Respiratory activity in sediments in three mountain lakes of the Julian Alps and in subalpine Lake Bled (Slovenia): an effect of altitude and antropic influence. Aquatic Microbial Ecology 34: 291-299.

Muskó, I. B., L. G.-Tóth \& E. Szábo, 1995. Respiration and respiratory electron transport system (ETS) activity of two amphipods: Corophium curvispinum G. O. Sars and Gammarus fossarum Koch. Polskie Archiwum Hydrobiologii 42: 547-558.

Nürnberg, G. K., 1996. Trophic state of clear and colored, softand hardwater lakes with special consideration of nutrients, 
anoxia, phytoplankton and fish. Lake and Reservoir Management 12: 432-447.

Osma, N., F. Maldonado, I. Fernández-Urruzola, T. T. Packard $\&$ M. Gomez, 2016. Variability of respiration and pyridine nucleotides concentration in oceanic zooplankton. Journal of Plankton Research 38: 537-550.

Owens, T. G. \& F. D. King, 1975. The measurement of respiratory electron transport system activity in marine zooplankton. Marine Biology 30: 27-36.

Pace, M. L. \& Y. T. Prairie, 2005. Respiration in lake. In Leb. Williams, P. J. \& P. del Giorgio (eds), Respiration in Aquatic Ecosystems. Oxford University Press, Oxford: $103-121$.

Packard, T. T., 1971. The measurement of respiratory electrontransport activity in marine phytoplankton. Journal of Marine Research 29: 235-244.

Packard, T. T., 1985. Measurement of electron transport activity of microplankton. In Jannash, H. \& P. J. Leb. Williams (eds), Advances in Aquatic Microbiology, Vol. 3. Academic Press, London: 207-261.

Packard, T. T., A. H. Devol \& F. D. King, 1975. The effect of temperature on the respiratory electron transport system in marine plankton. Deep Sea Research 22: 237-249.

Packard, T. T., N. Osma, I. Fernández-Urruzola, L. A. Codispoti, J. P. Christensen \& M. Gómez, 2015. Peruvian upwelling plankton respiration: calculations of carbon flux, nutrient retention efficiency, and heterotrophic energy production. Biogeosciences 12: 2641-2654.

Peñuelas, J., J. Murillo \& J. Azcón-Bieto, 1988. Actual and potential dark respiration rates and different electron transport pathways in freshwater aquatic plants. Aquatic Botany 30: 353-362.

Petersen, J. E. \& C. C. Chen, 1999. A method for measuring depth-integrated community metabolism in experimental planktonic-benthic ecosystems. Hydrobiologia 319: 23-32.

Sand-Jensen, K. \& A. Staehr, 2007. Scaling of pelagic metabolism to size, trophy and forest cover in small Danish lakes. Ecosystems 10: 127-141.

Scheffer, M., 1990. Multiplicity of stable states in freshwater systems. Hydrobiologia 200(201): 475-486.

Scheffer, M., 1998. Ecology of Shallow Lakes. Chapman and Hall, London: 357.

Simčič, T., 2005. The role of plankton, zoobenthos, and sediment in organic matter degradation in oligotrophic and eutrophic mountain lakes. Hydrobiologia 532: 69-79.

Simčič, T. \& A. Brancelj, 1997. Electron transport system (ETS) activity in five Daphnia species at different temperatures. Hydrobiologia 360: 117-125.

Simčič, T. \& A. Brancelj, 2002. Intensity of mineralization processes in mountain lakes in NW Slovenia. Aquatic Ecology 36: 345-354.

Simčič, T. \& A. Brancelj, 2009. Ecosystem health index (EHI) and electron transport system (ETS) activity of plankton and sediment in two lakes differing in trophic status. Fundamental and Applied Limnology 175(4): 317-326.

Simčič, T. \& M. Germ, 2009. Organic matter degradation through respiration in littoral and pelagial including profundal zones of an oligotrophic lake assessed by electron transport system activity. Hydrobiologia 635: 137-146.
Simčič, T. \& M. Germ, 2010. Increased temperature due to global warming alters the respiratory potential in aquatic organisms from an oligotrophic lake. International Review of Hydrobiology 95(4-5): 370-382.

Smith, C. S. \& M. S. Adams, 1986. Phosphorus transfer from sediments by Myriophyllum spicatum. Limnology and Oceanography 31: 1312-1321.

Søndergaard, M., J. P. Jensen \& E. Jeppesen, 2003. Role of sediment and internal loading of phosphorus in shallow lakes. Hydrobiologia 506-509: 135-145.

Staehr, P. A. \& K. Sand-Jensen, 2006. Seasonal changes in temperature and nutrient control of photosynthesis, respiration and growth of natural phytoplankton communities. Freshwater Biology 51: 249-262.

Szabó, E., 2003. The use of the tetrazolium reduction test for the detection of the terminal electron transport system (ETS) activity in decompositing reed (Phragmites austriacus/ Cav./Trin. Ex Steud.) rhiszome. Annales de Limnologie International Journal of Limnology 39: 63-70.

Tammeorg, O., T. Möls, J. Niemistö, H. Holmroos \& J. Horppila, 2017. The actual role of oxygen deficit in the linkage of the water quality and benthic phosphorus release: potential implications for lake restoration. Science of the Total Environment 599-600: 732-738.

Törnblom, E. \& K. Pettersson, 1998. Bacterial production and total sediment metabolism in profundal Lake Erken sediments. Archiv für Hydrobiologie. Special Issues Advances in Limnology 51: 177-183.

Tranvik, L. J., J. A. Downing, J. B. Cotner, S. A. Loiselle, R. G. Striegle, T. J. Ballatore, P. Dillon, K. Finlay, K. Fortino, L. B. Knoll, P. L. Kortelainen, T. Kutser, S. Larsen, I. Laurion, D. M. Leech, S. L. McCallister, D. M. McKnight, J. M. Melack, E. Overholt, J. A. Porter, Y. Prairie, W. H. Renwick, F. Roland, B. S. Sherman, D. W. Schindler, S. Sobek, A. Tremblay, M. J. Vanni, A. M. Verschoor, E. von Wachenfeldt \& G. A. Weyhenmeyera, 2009. Lakes and reservoirs as regulators of carbon cycling and climate. Limnology and Oceanography 54(6): 2298-2314.

Tuchman, N. C., M. A. Schollett, S. T. Rier \& P. Geddes, 2006. Differential heterotrophic utilization of organic compounds by diatoms and bacteria under light and dark conditions. Hydrobiologia 561: 167-177.

Vachon, D., C. T. Solomon \& P. A. del Giorgio, 2017. Reconstructing the seasonal dynamics and relative contribution of the major processes sustaining $\mathrm{CO}_{2}$ emissions in northern lakes. Limnology and Oceanography 62: 706-722.

Żbikowski, J., 2011. Macrozoobenthos of central parts of shallow lowland lakes of different types against a background of selected abiotic parameters of water and bottom sediments. Nicolaus Copernicus University. Habilitation Thesis: 232 pp. In Polish, summary in English.

Żbikowski, J. \& J. Kobak, 2007. Factors influencing taxonomic composition and abundance of macrozoobenthos in extralittoral zone of shallow, eutrophic lakes. Hydrobiologia 584: 145-155.

Zimmer, K. D., W. O. Hobbs, L. M. Domine, B. R. Herwig, M. A. Hanson \& J. B. Cotner, 2016. Uniform carbon fluxes in shallow lakes in alternative stable states. Limnology and Oceanography 61: 330-340. 